\title{
Physical, Optical, and Visual Performance of Coated Cross-Laminated Timber during Natural and Artificial Weathering
}

\author{
Gabrielly dos Santos Bobadilha ${ }^{1, *}$, C. Elizabeth Stokes ${ }^{1}$, Katie M. Ohno ${ }^{2}$, Grant Kirker ${ }^{2}{ }^{(}$, \\ Dercilio Junior Verly Lopes ${ }^{1}$ and Mojgan Nejad ${ }^{3}$ (D) \\ 1 Department of Sustainable Bioproducts, Forest and Wildlife Research Center (FWRC), \\ Mississippi State University, Starkville, MS 39762, USA; ces8@msstate.edu (C.E.S.); \\ dv123@msstate.edu (D.J.V.L.) \\ 2 Forest Products Laboratory-USDA, Madison, WI 53726, USA; katie.m.ohno@usda.gov (K.M.O.); \\ grant.kirker@usda.gov (G.K.) \\ 3 Department of Forestry, College of Agriculture \& Natural Resources, Michigan State University, East Lansing, \\ MI 48824, USA; nejad@msu.edu \\ * Correspondence: gd450@msstate.edu
}

check for

updates

Citation: Bobadilha, G.d.S.;

Stokes, C.E.; Ohno, K.M.; Kirker, G.;

Lopes, D.J.V.; Nejad, M. Physical,

Optical, and Visual Performance of

Coated Cross-Laminated Timber

during Natural and Artificial

Weathering. Coatings 2021, 11, 252.

https://doi.org/10.3390/

coatings11020252

Academic Editor: Anna Sandak

Received: 27 January 2021

Accepted: 18 February 2021

Published: 20 February 2021

Publisher's Note: MDPI stays neutral with regard to jurisdictional claims in published maps and institutional affiliations.

Copyright: (c) 2021 by the authors. Licensee MDPI, Basel, Switzerland. This article is an open access article distributed under the terms and conditions of the Creative Commons Attribution (CC BY) license (https:/ / creativecommons.org/licenses/by/ $4.0 /)$.

\begin{abstract}
Cross-laminated timber (CLT) market demand is on the rise in the United States. Adequate protective measures have not been extensively studied. The objective of this study was to investigate the weathering performance of exterior wood coatings. We evaluated coated CLT sample surfaces based on visual appearance, color change $\left(\mathrm{CIE}^{*} \mathrm{~L}^{*} \mathrm{a}^{*} \mathrm{~b}\right)$, gloss changes, and water intrusion. From the five exterior wood coatings evaluated, only two showed adequate performance after twelve months field exposure. Based on visual ratings following the ASTM procedures, coating failure occurs more quickly in Mississippi than in Wisconsin, due to its greater decay zone. Both location and coating type impacted the aging of the samples. Artificial weathering results were consistent with natural weathering indicating the two adequate coatings were the most resistant to failure, color, and gloss change. For future studies, new coatings designed for the protection of end-grain in CLT panels should be a target of research and development.
\end{abstract}

Keywords: mass-timber; surface protection; outdoor exposure; wood degradation; cross-laminated timber

\section{Introduction}

The use of cross-laminated timber (CLT) in construction has expanded across international markets because of its structural performance, seismic behavior, and sustainability [1-3]. CLT was introduced in North America in the early 2000 s, and since then research have been developed to expand its use across the building construction sector. In spite of recent advances, limited methods and technologies are readily available to prolong the durability of buildings composed of such material. Due to aesthetics, exterior CLT structural materials have been left unprotected, where they are either semi- or fully exposed to weathering [4]. In such conditions, surface degradation of uncoated CLT is very likely.

Although wood can be used exteriorly and interiorly, when uncoated and exposed to weather, wood surfaces deteriorate over time [5]. The natural properties and appearance of wood are compromised due to water and sun exposure. Repetitive cycles of wetting and drying cause alteration of chemical bonds and oxidation [6,7]. In addition to wetting, sun exposure can seriously damage the surface of wood materials since surface photooxidation is catalyzed by ultraviolet radiation [8,9]. The combined effects of moisture and solar exposure are primarily responsible for checking, splitting, surface erosion, and degradation caused by microorganisms [10].

The occurrence and development of mold, decay, and stains by fungi are related to climate conditions, such temperature and moisture [11]. In the Southern US, where 
temperature and humidity are high compared to other regions in the country, the color and appearance of wood are rapidly modified by weathering, mold, and stain fungi [12]. A study comparing climate index for decay in wood structures in three different states (MS, OR, and WI) showed that highest decay susceptibility was found in Mississippi [13].

Outdoor performance of CLT is still unknown in many parts of the US. However, the literature reports that its abundant storage capacity may lead to biodeterioration $[14,15]$. To expand the use of CLT in mid- and high-rise construction markets, more research is needed to implement proper codes for managing moisture and weathering degradation [16] Currently, there is a lack of studies on surface protection of mass timber exposed to outdoor environments. One of the reasons is that CLT was not primarily designed to be exteriorly exposed [16]. However, as its use increases throughout the country, more projects are designed with either full or partial external exposure. This study was designed to investigate the potential of readily available coatings in North America to protect CLT against weathering degradation.

Surface protection is generally used to maintain and prolong the aesthetics and service life of materials that may be affected by weathering factors during any stage from manufacturing to its end use. Paints, varnishes, stains, or water repellent coatings are commonly used to prevent weathering degradation [17]. They limit the passage of water in and out of wood, which may cause rapid dimensional changes [12]. In exterior applications, the use of penetrating semitransparent stains is recommended, since they do not crack or peel during exposure and are less influenced by dimensional changes caused by water differentials [18]. Proven hydrophobic coatings are recommended to be used without direct rainwater contact [19]. Consequently, the effectiveness of a finish is directly influenced by when and or where it is exposed. In a previous work, we investigated the use of ANN to predict color change based on visual grading on coated CLT naturally weathered in Mississippi [20]. In this study, our objective is to compare the performance of coated CLT exposed in Mississippi with the ones exposed in Madison. We also improve upon [20] by investigating gloss change and water uptake, which are properties that critically influence the correct deployment, preservation and maintenance of CLT.

\section{Materials and Methods}

\subsection{Sample Preparation and Coating Systems}

CLT blocks of hemlock-fir (Tsuga sp. and Abies sp.) were prepared from three-ply panels (SmartLam LLC; Whitefish, MT, USA) measuring $15 \mathrm{~cm} \times 14 \mathrm{~cm} \times 11 \mathrm{~cm}$. In a previous study, 12 coatings were investigated (including paints, stains and water relents named from A to L) [21], and based on a series of preliminary tests on their water-repellency and anti-swelling efficiency, the five best-performing coatings were selected for a second study, reported here (Table 1).

Table 1. Coating treatment specifications.

\begin{tabular}{|c|c|c|c|c|}
\hline Treatment & $\begin{array}{l}\text { Coating or Surface } \\
\text { Description }\end{array}$ & Resin Type & No. of Coats & No. of Reps \\
\hline $\mathrm{A}\left(\mathrm{Alk} / \mathrm{Acr}, \mathrm{W}^{1}\right)$ & $\begin{array}{l}\text { Transparent penetrating } \\
\text { wood finish }\end{array}$ & Alkyd/Acrylic & 2 & 6 \\
\hline C (Alk/Acr, W) & Transparent, UV resistant & Alkyd/Acrylic & 3 & 6 \\
\hline $\mathrm{F}(\mathrm{Acr}, \mathrm{W})$ & $\begin{array}{c}\text { Semi-transparent, water and } \\
\text { UV resistant }\end{array}$ & Acrylic & 2 & 6 \\
\hline $\mathrm{I}\left(\mathrm{Alk}, \mathrm{S}^{2}\right)$ & $\begin{array}{l}\text { Transparent, mildew and } \\
\text { water resistant }\end{array}$ & Alkyd & 2 & 6 \\
\hline $\mathrm{J}(\mathrm{Alk}, \mathrm{S})$ & $\begin{array}{l}\text { Semitransparent and water } \\
\text { repellent }\end{array}$ & Alkyd & 1 & 6 \\
\hline Control & Uncoated sample & None & None & 6 \\
\hline
\end{tabular}


Coatings were applied on unprimed CLT samples with foam brush on the top surface and sides in accordance with manufacturer recommendation.

\subsection{Natural and Artificial Weathering}

CLT samples were exposed for 12 months (June 2019-June 2020) in Madison, Wisconsin (AWPA hazard zone 2) and in Starkville, Mississippi (AWPA hazard zone 4). Normally, exterior wood coatings exposed to natural weathering are tested on vertical positions with minimum length dimension of $152 \mathrm{~mm}$ [22]. Since the CLT samples were thicker, the samples contained different dimensions, and racks were designed to horizontally expose the samples. In Madison, the exposure site was located at the Forest Products Laboratory (FPL, Madison, WI, USA) Valley View field site. The CLT samples were atop racks that were constructed with garden mesh to avoid water trapping underneath the test samples. An overview of the climatic conditions during one year of natural weathering exposure is displayed in Table 2. One sample per treatment was left unexposed in an environmental chamber at $25^{\circ} \mathrm{C}$ and $66 \% \mathrm{RH}$ for each set of samples for further comparison.

Table 2. Weather conditions in Mississippi and Wisconsin during natural outdoor exposure of coated and uncoated CLT samples, adapted from [23,24].

\begin{tabular}{|c|c|c|c|c|}
\hline \multirow{3}{*}{$\begin{array}{l}\text { 2019/2020 } \\
\text { Months }\end{array}$} & \multicolumn{4}{|c|}{ Mississippi * } \\
\hline & \multicolumn{4}{|c|}{ Weather Conditions } \\
\hline & $\begin{array}{c}\text { Mean Temperature } \\
\left({ }^{\circ} \mathrm{C}\right)\end{array}$ & $\begin{array}{c}\text { Total Precipitation } \\
(\mathrm{mm})\end{array}$ & $\begin{array}{c}\text { Mean Radiation } \\
\left(\mathrm{kW}-\mathrm{h} / \mathrm{m}^{2}\right)\end{array}$ & Total Snow (mm) \\
\hline Jun (0) & 26 & 211.6 & 6.3 & - \\
\hline Jul (1) & 27.5 & 271.3 & 6.5 & - \\
\hline Aug (2) & 27.5 & 140.5 & 6.4 & - \\
\hline Sept (3) & 27.5 & 1 & 6.1 & - \\
\hline Oct (4) & 19.2 & 278.4 & 4.5 & - \\
\hline Nov (5) & 9.3 & 93.7 & 3.3 & - \\
\hline $\operatorname{Dec}(6)$ & 9.9 & 172.5 & 2.7 & - \\
\hline Jan (7) & 9.4 & 261.1 & 2.9 & - \\
\hline Feb (8) & 9.3 & 373.4 & 3.7 & - \\
\hline Mar (9) & 16.8 & 180.8 & 4.9 & - \\
\hline Apr (10) & 16.1 & 287.3 & 6.1 & - \\
\hline May (11) & 20.5 & 46.2 & 6.5 & \\
\hline \multirow[t]{2}{*}{ Jun (12) } & 25.7 & 137.2 & 6.5 & - \\
\hline & \multicolumn{4}{|c|}{ Wisconsin } \\
\hline Jun (0) & 19.2 & 131.1 & 6.8 & - \\
\hline Jul (1) & 24 & 146.6 & 6.7 & - \\
\hline Aug (2) & 20.3 & 72.4 & 6 & - \\
\hline Sept (3) & 18.9 & 172.7 & 4.9 & - \\
\hline Oct (4) & 9.2 & 140.7 & 3.4 & 205.7 \\
\hline Nov (5) & -0.5 & 66.8 & 2.1 & 193.0 \\
\hline Dec (6) & -1.1 & 38.6 & 1.6 & 73.7 \\
\hline $\operatorname{Jan}(7)$ & -3.2 & 1.7 & 1.9 & 464.82 \\
\hline Feb (8) & -4.9 & 0.9 & 2.9 & 337.8 \\
\hline Mar (9) & 3.6 & 88.1 & 4.1 & 71.2 \\
\hline Apr (10) & 7.2 & 52.1 & 5.2 & 5.1 \\
\hline May (11) & 13.5 & 137.7 & 6.2 & - \\
\hline Jun (12) & 21.2 & 129.5 & 6.8 & - \\
\hline
\end{tabular}

${ }^{*}$ Data from Mississippi were previously published [20].

The artificial weathering test was conducted in a weathering apparatus that consisted of a stainless-steel cabinet equipped with water spray, UV lamps, and temperature controlled forced air heating elements that simulated exterior conditions by alternating each cycle of irradiation and water. The unit was equipped with UV-A lamps $\left(600 \mathrm{~W} \cdot \mathrm{m}^{-2}\right.$ at $340 \mathrm{~nm}$ ), maintaining an average temperature of $26^{\circ} \mathrm{C}$. The samples were exposed 
to weathering cycles of $12 \mathrm{~h}$ of UV-light irradiation and $12 \mathrm{~h}$ of water spray $(0.36 \mathrm{Lpm})$ for an accelerated 15 days $(360 \mathrm{~h})$ and a longer term of 75 days $(1800 \mathrm{~h})$. The test panels were placed at a $45^{\circ}$ angle and assignment of board location was randomized to eliminate potential position bias.

\subsection{Surface Appearance Analysis}

At the end of each month, superficial damage was evaluated according to the American Standard and Testing Materials [25-31]. Cracking, flaking, mildew growth and erosion were visually distinguishable after three months of exposure; Figure 1 shows the most common defects found on samples surface.

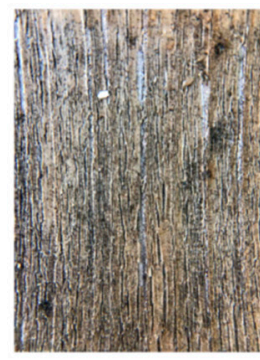

(a)

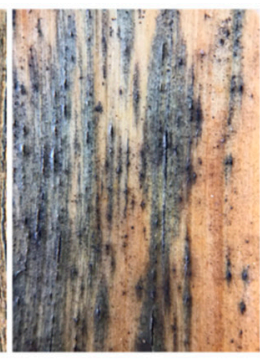

(b)

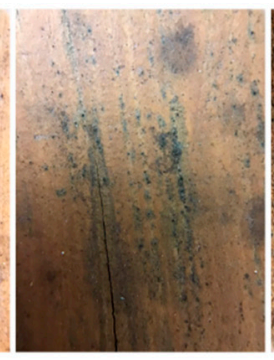

(c)

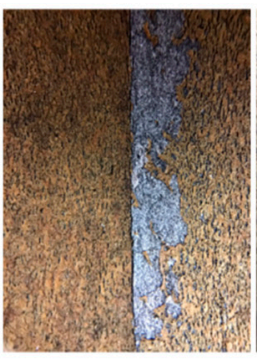

(d)

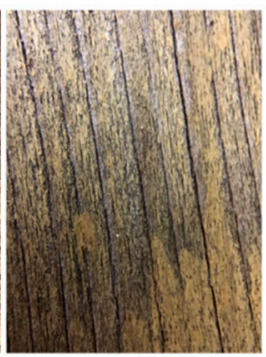

(e)

Figure 1. Types of coating failure after natural weathering exposure. (a) Several types of micro-checks and micro-cracks; (b) irregular micro-checks; (c) long line checks; (d) combination of checks, cracks, flaking, and erosion; (e) advanced coating erosion.

Stain and paint failures were evaluated by comparison with photographic standards. Degrees of cracking, flaking, and erosion range from 0 (complete failure) to 10 (no visible defect). Each procedure describes one type of failure. For example, cracking is manifested as breaking of paint or stain only where underlying surface is visible. Flaking is classified as detachment of coating from its substrate. Erosion describes paint removal that displays bare wood surface. Mold growth ratings followed the similar principle, where 0 described full coverage and 10 no visual growth (Figure 2).

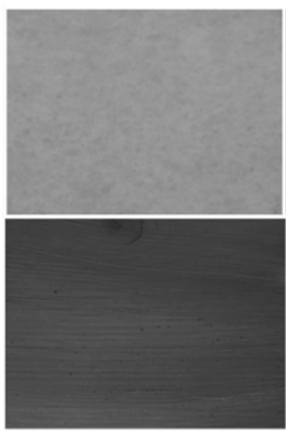

(a)

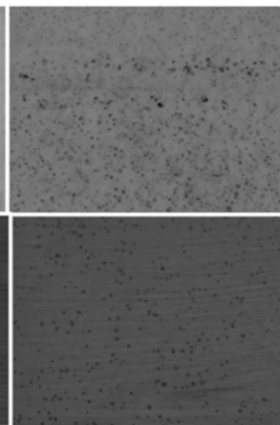

(b)

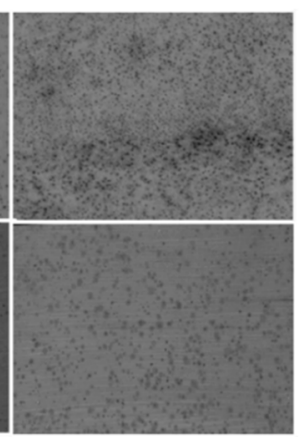

(c)

Figure 2. Mildew growth: (a) slight; (b) moderate, and; (c) severe mold pictures. First row corresponds to reference pictures [26], second row contains the mildew growing on CLT samples surface.

\subsection{Color and Gloss Measurements}

The color parameters of the tested blocks were measured using a hand-held spectrophotometer (CM-2300d, Konica Minolta, Osaka, Japan). Both natural and artificially weathered samples were evaluated, and five measurements were taken at the same location of each specimen following the Commission International de l'Eclairage [32] colorimetry method using color parameters $\left(L^{*} a^{*} b^{*}\right)$. Where $L^{*}$ represents lightness from 0 (black) to 100 (white), $a^{*}$ chromaticity coordinates red $(+)$ or green $(-)$, and $b^{*}$ chromaticity coordinates 
yellow (+) or blue (-). The color changes $\left(\Delta L^{*}, \Delta a^{*}, \Delta b^{*}\right)$ between the exposed period and initial state were determined. Color differences were calculated using Equation (1).

$$
\Delta E^{*}=\sqrt{\Delta L^{* 2}+\Delta a^{* 2}+\Delta b^{* 2}}
$$

The surface luster of samples was measured using a glossmeter ETB-0686 following ISO 2813 [33]. Three measurements were made on each sample at a $60^{\circ}$. Alterations of the surface luster of coated and uncoated samples were assessed at the end of each month or at the end of the artificial weathering cycle. Results were based on a specular gloss value of 96 gloss units (GU), related to the perfect condition under identical illumination and view conditions of highly polished plain black glass surface. Color and gloss measurements were recorded at 0,6 , and 12 months after exposure.

\subsection{Moisture Content during Exposure}

During the manufacturing process, CLT is often only glued between layers and not on the sides. For this reason, all exposed surfaces contained an edge joint. At the end of each month for 6 months, and then after 12 months, all exposed samples were weighed to determine the mass. The initial weight was taken when the samples were already coated and at equilibrium moisture content $(\mathrm{EMC}=12 \%)$ after 45 days in environmental chamber at $25^{\circ} \mathrm{C}$ and $66 \% \mathrm{RH}$. Moisture content (MC) was calculated as displayed in Equation (2):

$$
\mathrm{MC}=\frac{W_{2}-W_{1}}{W_{1}} \times 100
$$

where:

$\mathrm{MC}=$ moisture content after exposure in \%,

$W_{2}$ = final weight gain in $g$,

$W_{1}=$ initial weight gain in $\mathrm{g}$.

\subsection{Statistical Analysis}

Statistical Analysis of Variance (ANOVA) were performed for artificial weathering test variables. Color and gloss changes were analyzed as completely randomized design based on coating effect. Tests were performed at $\alpha=0.05$, when the sources of variations were detected as significant by the Fisher-test $(p \leq 0.05)$. Analyses were performed using Statistical Analysis System (SAS) software version 9.4 [34].

\section{Results and Discussion}

\subsection{Natural Weathering}

\subsubsection{Visual Assessments}

The types of failure present on coatings were mainly fungal growth, cracking, flaking, and erosion, consequently the samples were evaluated according to those characteristics (Table 3). Location had a great impact on coating degradation. For instance, after 3 months, all samples displayed mildew growth in Mississippi.

In Wisconsin, coating F Acr protected the samples against mildew until three months of exposure; however, after six months, mildew growth was visible. Coating C Alk/Acr as well did not show any mildew growth even after 6 months of exposure. Figure 3 shows surface degradation over time for all coatings tested in comparison to uncoated controls. 
Table 3. Average visual rating for coatings after 3, 6 and 12 months of outdoor exposure in Mississippi and Wisconsin, reported as mean and standard deviation in parenthesis.

\begin{tabular}{|c|c|c|c|c|c|c|}
\hline \multirow[t]{3}{*}{ Coatings } & \multicolumn{3}{|c|}{ Mississippi ${ }^{1}$} & \multicolumn{3}{|c|}{ Wisconsin } \\
\hline & \multicolumn{6}{|c|}{ Mildew Growth } \\
\hline & 3 & 6 & 12 & 3 & 6 & 12 \\
\hline $\begin{array}{c}\text { A. } \\
\text { Alk/Acr }\end{array}$ & $4(1.0)$ & $3(1.4)$ & $7(0.8)$ & $7(1.1)$ & $5(0.7)$ & $5(1.0)$ \\
\hline C. AlkAcr & $9(0.5)$ & $7(1.1)$ & $7(1.1)$ & $10(0.5)$ & $10(0.9)$ & $8(0.8)$ \\
\hline F. Acr & $7(1.1)$ & $5(0.8)$ & $5(0.0)$ & $10(0.4)$ & $8(0.5)$ & $9(0.5)$ \\
\hline I. Alk & $7(1.3)$ & $4(0.9)$ & $9(0.5)$ & $7(0.8)$ & $6(1.3)$ & $5(0.9)$ \\
\hline J. Alk & $1(0.6)$ & $1(0.0)$ & $5(1.6)$ & $6(0.5)$ & $3(0.4)$ & $4(0.4)$ \\
\hline \multirow[t]{3}{*}{ Control } & $5(1.2)$ & $5(1.1)$ & $9(0.7)$ & $7(0.5)$ & $7(0.0)$ & $9(0.5)$ \\
\hline & \multicolumn{6}{|c|}{ Checking } \\
\hline & 3 & 6 & 12 & 3 & 6 & 12 \\
\hline $\begin{array}{c}\text { A. } \\
\text { Alk/Acr }\end{array}$ & $6(0.9)$ & $4(2.3)$ & $0(1.1)$ & $6(1.4)$ & $4(0.9)$ & $0(0.0)$ \\
\hline $\begin{array}{c}\text { C. } \\
\text { Alk/Acr }\end{array}$ & $10(0.0)$ & $8(1.8)$ & $8(2.2)$ & $10(0.0)$ & $8(1.1)$ & $8(1.7)$ \\
\hline F. Acr & $10(0.9)$ & $10(0.9)$ & $8(1.9)$ & $8(0.9)$ & $8(0.0)$ & $8(0.0)$ \\
\hline I. Alk & $8(1.1)$ & $6(1.1)$ & $2(3.6)$ & $10(0.0)$ & $8(0.0)$ & $4(1.1)$ \\
\hline \multirow[t]{3}{*}{ J. Alk } & $6(1.7)$ & $2(1.1)$ & $2(1.7)$ & $6(1.7)$ & $8(1.1)$ & $2(0.0)$ \\
\hline & \multicolumn{6}{|c|}{ Flaking } \\
\hline & 3 & 6 & 12 & 3 & 6 & 12 \\
\hline $\begin{array}{c}\text { A. } \\
\text { Alk/Acr }\end{array}$ & $8(1.4)$ & $6(1.1)$ & $2(1.1)$ & $10(0.0)$ & $6(1.7)$ & $0(0.0)$ \\
\hline $\begin{array}{c}\text { C. } \\
\text { Alk/Acr }\end{array}$ & $10(0.0)$ & $10(0.0)$ & $8(2.2)$ & $10(0.0)$ & $10(0.0)$ & $4(1.1)$ \\
\hline F. Acr & $10(0.0)$ & $10(0.0)$ & $10(0.0)$ & $10(0.0)$ & $10(0.0)$ & $10(0.0)$ \\
\hline I. Alk & $10(1.8)$ & $8(0.9)$ & $6(1.7)$ & $8(0.0)$ & $6(1.1)$ & $4(1.1)$ \\
\hline \multirow[t]{3}{*}{ J. Alk } & $6(1.1)$ & $4(0.9)$ & $4(2.3)$ & $8(1.1)$ & $8(1.1)$ & $4(0.0)$ \\
\hline & \multicolumn{6}{|c|}{ Erosion } \\
\hline & 3 & 6 & 12 & 3 & 6 & 12 \\
\hline $\begin{array}{c}\text { A. } \\
\text { Alk/Acr }\end{array}$ & $10(0.0)$ & $8(1.1)$ & $4(1.1)$ & $6(1.7)$ & $4(0.0)$ & $0(0.0)$ \\
\hline $\begin{array}{c}\text { C. } \\
\text { Alk/Acr }\end{array}$ & $10(0.0)$ & $10(0.0)$ & $10(0.0)$ & $10(0.0)$ & $10(0.0)$ & $8(0.9)$ \\
\hline F. Acr & $10(0.0)$ & $10(0.0)$ & $10(0.0)$ & $10(0.0)$ & $10(0.0)$ & $10(1.1)$ \\
\hline I. Alk & $10(0.9)$ & $10(0.9)$ & $6(2.0)$ & $8(0.0)$ & $8(1.1)$ & $8(0.9)$ \\
\hline J. Alk & $8(1.4)$ & $8(1.1)$ & $6(1.7)$ & $6(2.3)$ & $6(0.0)$ & $8(0.0)$ \\
\hline
\end{tabular}

${ }^{1}$ Not applicable for uncoated samples. Mississippi results previously published [20].

In Wisconsin, mildew growth increased over time on the sample surfaces, except for the coating J Alk and the control. In Mississippi, a similar trend occurred after 3 and 6 months of exposure, yet after 12 months, mildew decreased. Coatings A and J had noticeably worse performance in Mississippi, most likely due to climate conditions such as higher temperature and humidity (see Table 1). In fact, the essential condition for mildew growth is a sporadic supply of free water. Coatings A Acr/Alk and J Alk were fairly eroded over time, and thus did not promote enough protection. Stirling [35] pointed out that semitransparent wood coatings (e.g., coating J Alk) frequently present signs of early discoloration caused by "black stain" fungi. Coatings C Acr/Alk and F Acr had better performance against mildew because of anti-microbial ingredients present in their composition. For instance, coating C Acr/Alk is composed of two antimicrobial agents (n-n diethylethanamine, DMEA and 3-iodo-2 propynyl butyl carbamate, IPBC), while coating $\mathrm{F}$ Acr only contains IPBC. As temperature increases, IPBC may degrade or evaporate [36]. 


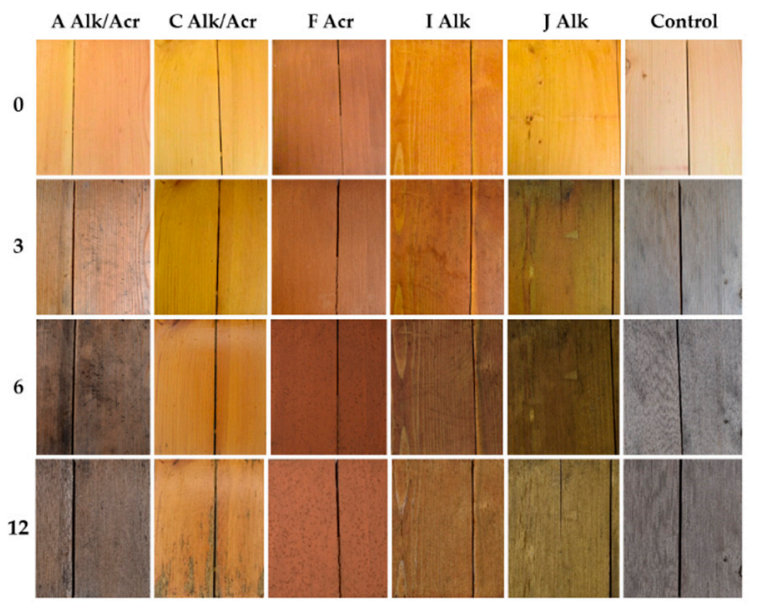

(a)

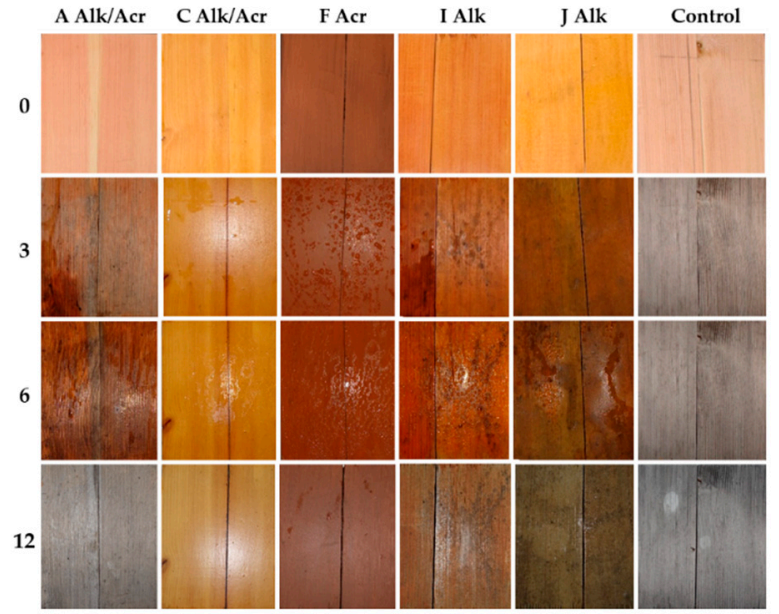

(b)

Figure 3. Visual changes of uncoated and coated CLT samples after twelve months of natural weathering in (a) Mississippi and (b) Wisconsin.

On coating degradation, we observed that most samples surfaces had more than one type of failure after twelve months of exposure; however, the most frequent were checking, flaking, and surface erosion. Most coating performance varied due to site location and time. However, checking assessments had low variations due to location. Overall, coating F Acr had the lowest degree of checking and flaking. Coatings I Alk presented checking earlier (three months of exposure) in Mississippi; yet in Wisconsin, checks were visible only after six months. Coating A Alk/Acr had the worst performance, with a high degree of degradation expressed with flaking and checking at both locations after 12 months of exposure. These failures advanced to surface erosion and a complete removal of the coating. Based on the manufacturer's information, coatings A Alk/Acr and J Alk are penetrating stains that, according to Roux et al. [37], are more likely to fail after a short period of outdoor exposure. Coating F Acr showed no visible sign of erosion in either location. CLT defects on the exposed surface influenced coatings efficiency. The minimum visual grade of longitudinal CLT layers is No. 2 [38], characterized by having knots and wane. Most samples had few defects on the exposed layer but when they did, coating failure was seen earlier.

CLT samples with higher proportions of latewood had early coating deterioration. For the purpose of coating, a high proportion of earlywood is desirable; however, in structural wood products such as CLT, it may result in tangential shrinkage and low stability [39]. As softwood life-cycles are becoming shorter, it is more common to find lumber with a high percentage of earlywood. According to [5], some species that have wide bands of earlywood and latewood do not absorb paint and coatings well. This variation creates stresses such as breaking adhesion between coating and wood resulting in checks and cracks. Penetrating coatings such as A Alk/Acr and J Alk were visually eroded after three months of exposure, whereas film forming coatings were not. Penetrating coatings perform better on porous surfaces. In our study, we exposed the tangential surface, and therefore coatings could not penetrate into the cells.

\subsubsection{Color and Gloss Change}

The color parameters $\left(L^{*}, a^{*}\right.$, and $\left.b^{*}\right)$ were evaluated based on type of coating, site location, and duration of exposure ( $0,3,6$, and 12 months of weathering). Coatings provided a degree of protection against ultraviolet degradation. However, they (except $F$ Acr) expressed some type of discoloration as observed in changes in lightness (brightness) and color after irradiation in either location (Figure 4). 
(a)

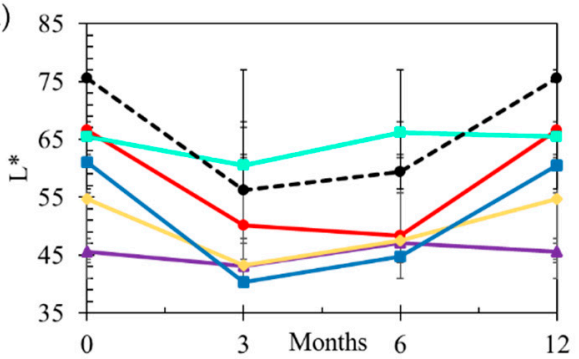

(b)

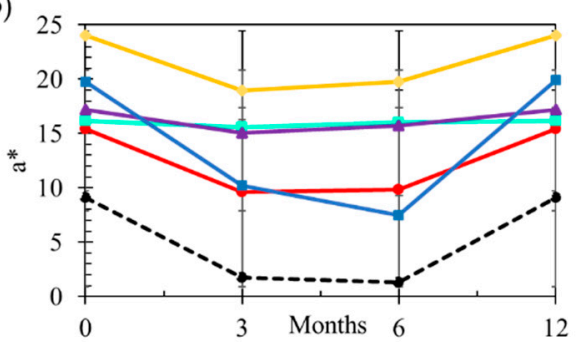

(c)

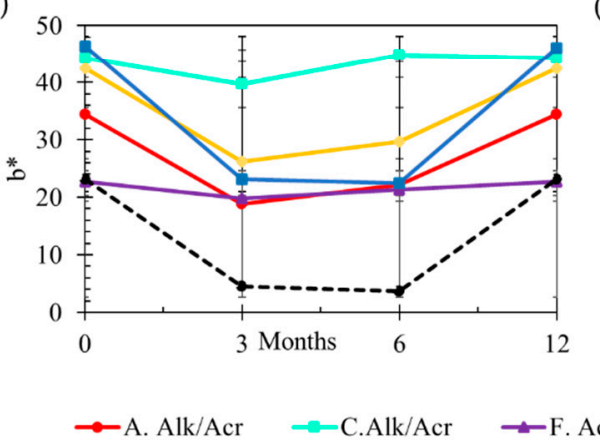

(d) 8

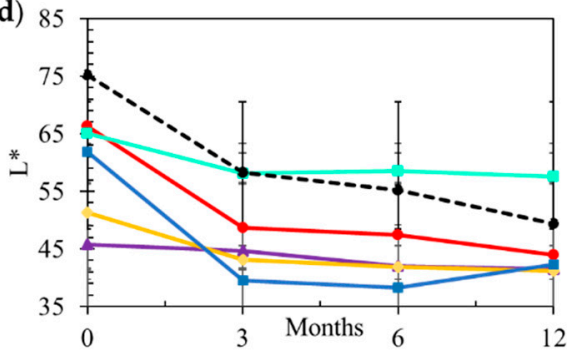

(e)

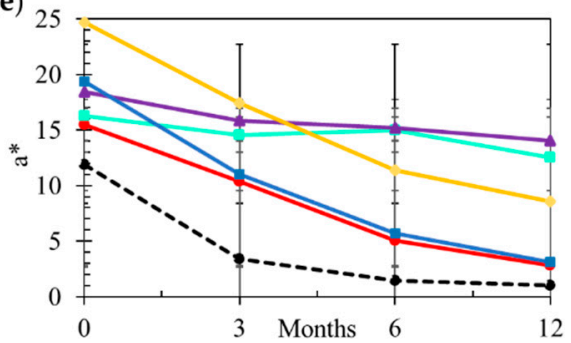

(f)

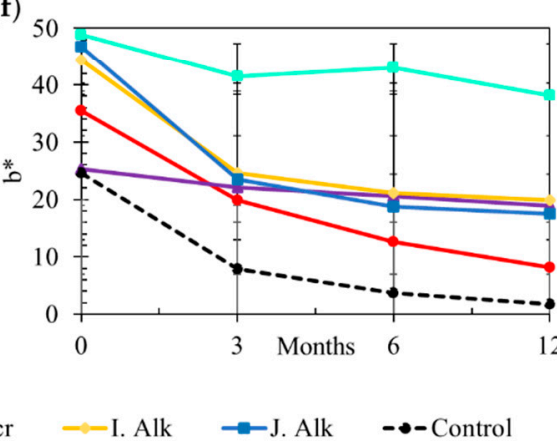

Figure 4. Describes CIELAB color parameters measured during 12 months of exposure. Graphs (a), (b), and (c) respectively display $L^{*}$ lightness, $a^{*}$ red to green, $b^{*}$ yellow to blue variations in Wisconsin, and (d), (e), (f) respectively: $L^{*}, a^{*}$, and $b^{*}$ variations in Mississippi. Error bars represent standard deviation at $95 \%$ of confidence interval.

One year of weathering exposure in Mississippi and Wisconsin showed that different climate conditions impact performance of both coatings and wood. Samples exposed in Mississippi decreased in lightness and color as time progressed. In Wisconsin, there was no specific trend in color discoloration of samples, and alterations in lightness and color were expressed only in first three months and after one year. Rapid discoloration of surfaces can be associated with higher temperatures and UV light between the initiation of the experiment and the first data collection (June and September).

Overall, coatings F Acr and C Alk/Acr were less susceptible to color degradation over time. Even though literature reports low photo-degradation resistance of clear coatings, coating C Alk/Acr was the second most stable color. Coating J Alk was the most susceptible to both darkening and color change. As mentioned in Section 3.1.1, the surface of the J Alk samples was completely covered with mold. Fungal growth is the major cause of surface graying when moisture is present [40]. They usually produce dark colored spores and mycelia that may grow on either raw or coated wood surfaces that gives the weathered wood on color change overtime. Coating J Alk also degraded faster than the other finishes.

Initial gloss of samples before installation varied between was initially very low ranging between 2-10 GU (except for coating C Alk/Acr around $20 \mathrm{GU}$ ), due to both wood surface variation and coating type. Overall, the outdoor exposure did not affect the gloss of coatings A Alk/Acr, F Acr, and J Alk or the uncoated control samples (Figure 5). 


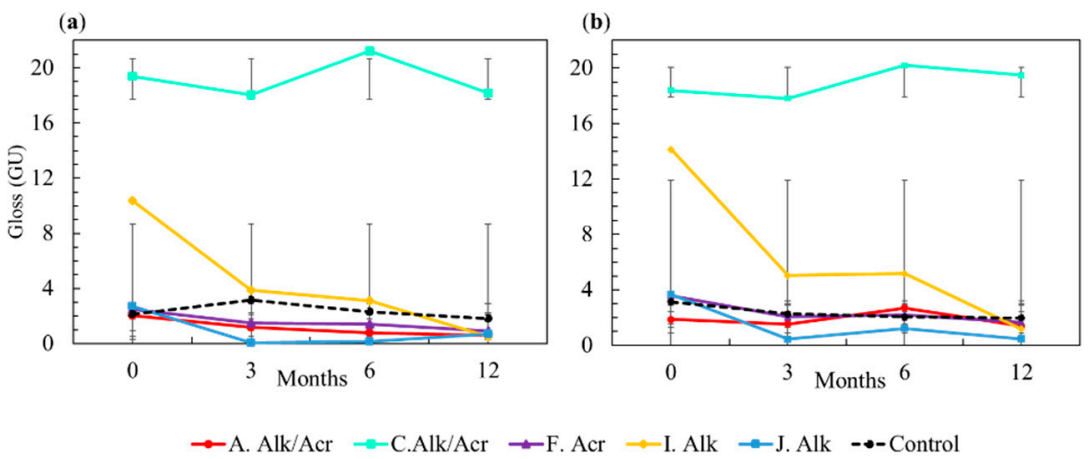

Figure 5. Gloss variation (GU) of tested coatings exposed to natural weathering in (a) Mississippi and (b) Wisconsin.

Coatings I Alk and C Alk/Acr were the least resistant to gloss change. Loss of gloss is an indicator of initial degradation and is caused by either non-chemical changes (e.g., cracking, checking) or by chemical changes located in the topmost portion of the coating [41]. Since some coatings had very low gloss values before exposure due to their opaque nature (e.g., coating J), alterations to their surface luster were not detected.

\subsubsection{Moisture Content during Exposure}

The differences in moisture content of samples exposed in Mississippi compared to Wisconsin were closely related to weathering factors such as temperature, precipitation, and radiation. Moisture content increase in samples exposed in Wisconsin was higher. Low temperatures were reported at the site, along with snow and ice (Figure 6).
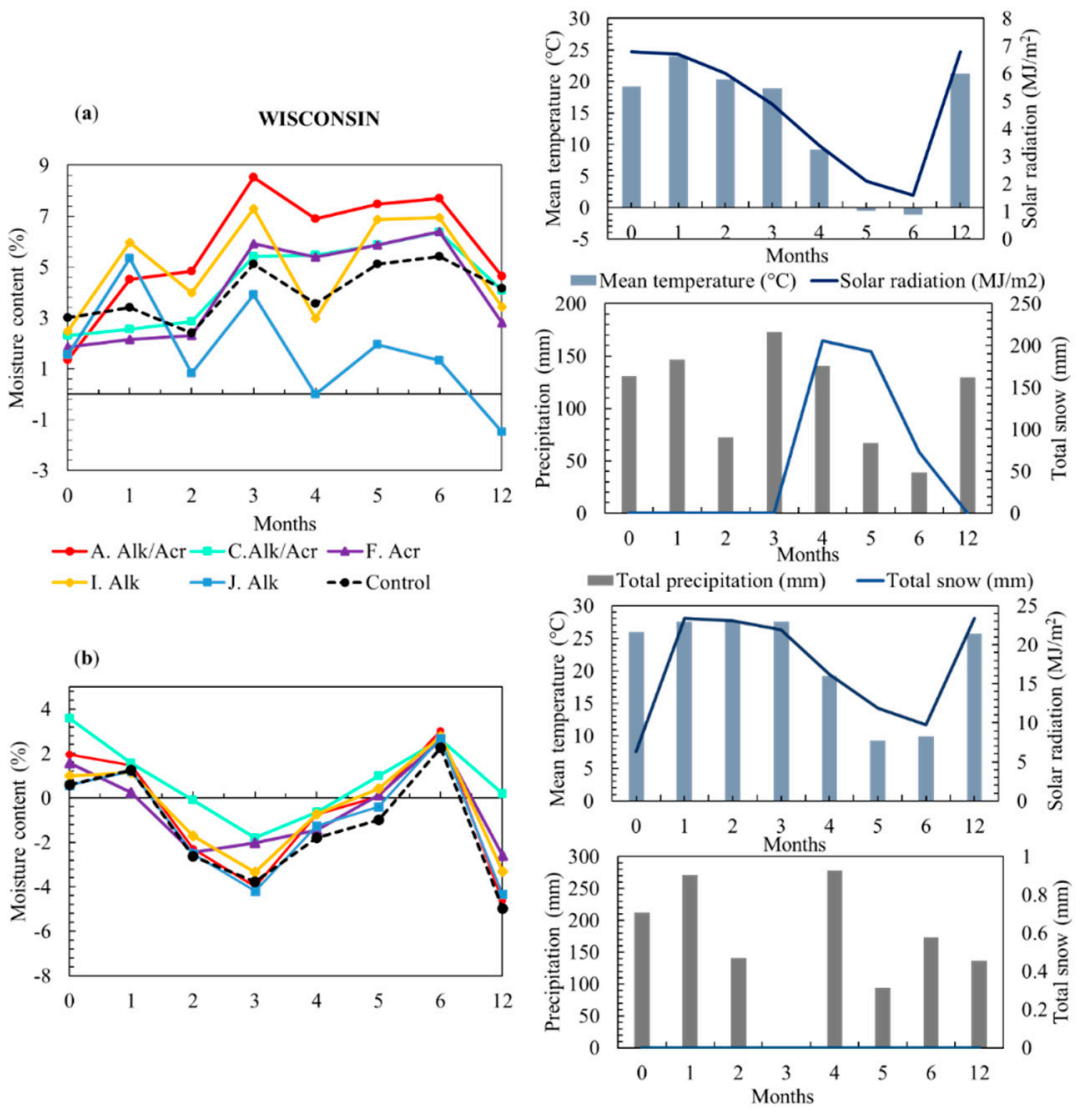

Figure 6. Moisture content of uncoated and coated samples exposed to 12 months of natural weathering in (a) Wisconsin and (b) Mississippi. 
Even though the precipitation in Mississippi was higher, the intense solar radiation and high temperatures resulted in lower moisture content. Differences in temperature cause stress to any material due to gradients of thermal expansion [42]. Shrinking and swelling can result in coating and adhesive failure. In Mississippi, for example, three samples had adhesive failure because of dimensional changes resulted from differential in moisture and temperature (Figure 7).
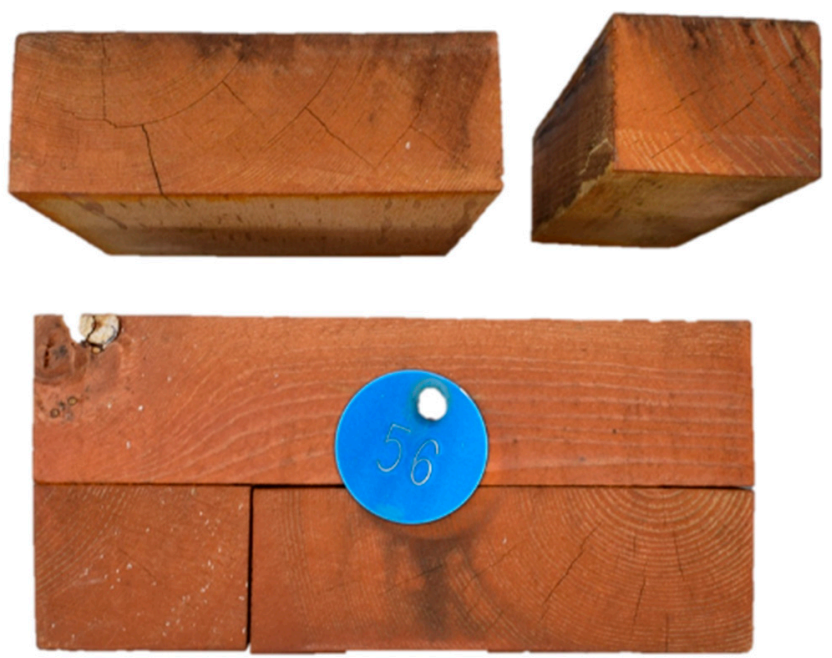

Figure 7. Delamination of coated CLT (I Alk) after 12 months of outdoor exposure.

Another factor that may have impacted increase in moisture content is the end joint present in each sample. Many CLT panels manufactured in North America are not edge glued, i.e., they are only glued between each layer, and not on the sides. These spaces may trap water and weaken the bond between wood and adhesive. Water absorption in CLT during service raises concerns with respect to the dimensional stability and durability of wood. Polyurethanes are the most common adhesive in CLT production because of its considerable resistance to water and fire [43]. However, combinations of liquid water, shrinking, and swelling tend to break chemical bonds between wood and adhesive resulting in CLT delamination. High moisture content also contributes to mold and decay development [15].

\subsection{Artificial Weathering}

\subsubsection{Visual Analysis}

The transparent and semi-transparent coatings had different performance during artificial exposure. The coatings A Acr/Alk, J Alk, and I Alk presented some type of chalking that occasionally could result in surface erosion. It is important to mention that some studies describe degradation of clear coating as cracking or flaking. The type of degradation found for the opaque coatings used in this study (A Acr/Alk and J Alk) were best described as chalking due to their powdery appearance (Figure 8).

Although the short-term exposure resulted in no major visual change on most of the treatments, coating I exhibited decrease in brightness with some degree of bleaching. Similar results were found on commercial coatings after $1000 \mathrm{~h}$ of accelerated weathering [43]. The long exposure of $1800 \mathrm{~h}$ resulted in slight chalking of coatings $\mathrm{A}$ and $\mathrm{J}$ and moderate chalking of coating I. 


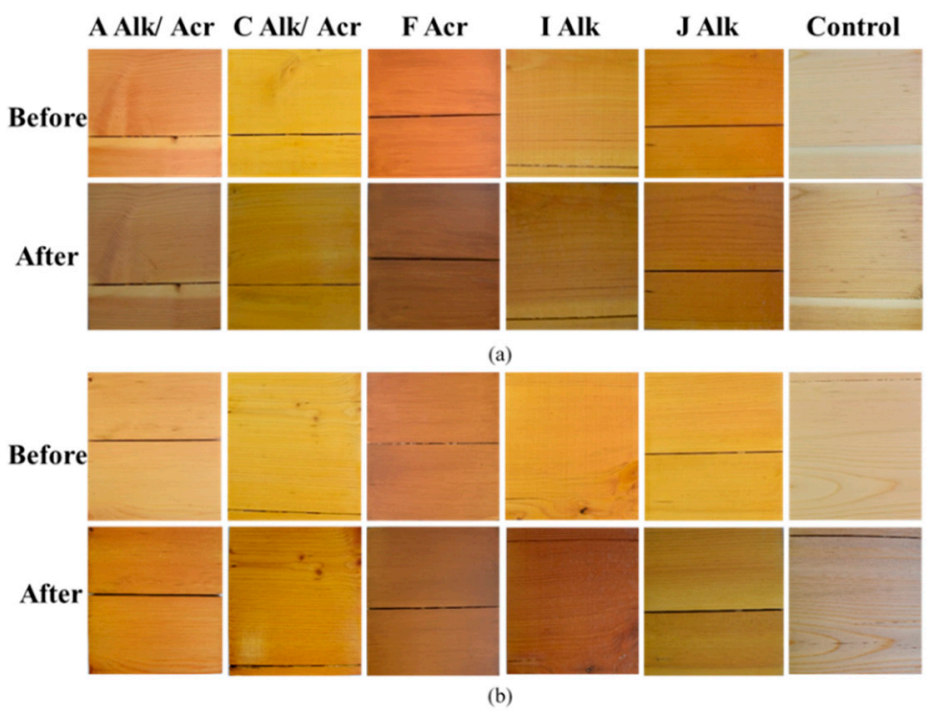

Figure 8. Surface change of selected tested samples. First and second rows correspond to before and after exposure, respectively. (a) After $360 \mathrm{~h}$ of exposure; and (b) after $1800 \mathrm{~h}$ of exposure.

\subsubsection{Color and Gloss Changes}

The color changes of coated and uncoated CLT samples exposed for $360 \mathrm{~h}$ and $1800 \mathrm{~h}$ are summarized in Table 4 . Although short-term exposure $(360 \mathrm{~h})$ showed discrete changes, there was statistical difference between treatments $(\alpha=0.05)$. Overall, coating did not express great lightness degradation $\left(\Delta L^{*}\right)$ in the first accelerated weathering test except for coating J ( -4.8 units). The lowest value of $\Delta L^{*}$ was reported for untreated samples ( -10.4 units) that became darker after the test. This result was expected because wood chemical components, such as extractives, rapidly degrade with photo-radiation exposure leaving them darker [41].

Table 4. Color change values of artificial weathered CLT samples. Mean and (standard deviation).

\begin{tabular}{ccccccccc}
\hline \multirow{2}{*}{ Coating } & \multicolumn{3}{c}{$360 \mathrm{~h}$} & \multicolumn{7}{c}{ CIE Lab Coordinates } \\
\cline { 2 - 9 } & $\boldsymbol{\Delta} \boldsymbol{L}^{*}$ & $\boldsymbol{\Delta} \boldsymbol{a}^{*}$ & $\boldsymbol{\Delta} \boldsymbol{b}^{*}$ & $\boldsymbol{\Delta} \boldsymbol{E}^{*}$ & $\boldsymbol{\Delta} \boldsymbol{L}^{*}$ & $\boldsymbol{\Delta} \boldsymbol{a}^{*}$ & $\boldsymbol{\Delta} \boldsymbol{b}^{*}$ & $\boldsymbol{\Delta} \boldsymbol{E}^{*}$ \\
\hline A. & -2.6 & -0.9 & 0.2 & 2.9 & -12.9 & 3.2 & -1.3 & 13.4 \\
Alk/Acr & $(1.3)$ & $(0.5)$ & $(0.7)$ & $(1.1)$ & $(1.4)$ & $(0.7)$ & $(0.8)$ & $(1.5)$ \\
\hline C. & -1.2 & 0.0 & -1.1 & 1.8 & -7.6 & 3.0 & -3.4 & 8.9 \\
Alk/Acr & $(0.2)$ & $(0.6)$ & $(0.7)$ & $(0.7)$ & $(1.1)$ & $(0.4)$ & $(0.2)$ & $(1.0)$ \\
\hline \multirow{2}{*}{ F. Acr } & 1.5 & -0.2 & -0.3 & 1.7 & -1.7 & -1.3 & -1.6 & 2.9 \\
& $(2.2)$ & $(0.2)$ & $(0.3)$ & $(2.1)$ & $(0.4)$ & $(1.3)$ & $(0.3)$ & $(0.8)$ \\
\hline \multirow{2}{*}{ I. Alk } & -1.6 & 0.3 & -3.5 & 4.2 & -11 & -0.6 & -12.6 & 16.9 \\
& $(1.7)$ & $(1.3)$ & $(2.7)$ & $(2.9)$ & $(2.2)$ & $(1.0)$ & $(3.9)$ & $(4.2)$ \\
\hline \multirow{2}{*}{ J. Alk } & -4.8 & -0.4 & -2.4 & 5.5 & -12 & 0.7 & -6.7 & 13.9 \\
& $(0.5)$ & $(1.0)$ & $(0.4)$ & $(0.4)$ & $(0.6)$ & $(1.7)$ & $(1.9)$ & $(0.4)$ \\
\hline \multirow{2}{*}{ Control } & -10.4 & 2.0 & 7.3 & 12.6 & -11.3 & -0.8 & -5.5 & 13 \\
& $(0.8)$ & $(1.0)$ & $(1.8)$ & $(1.8)$ & $(0.2)$ & $(0.6)$ & $(1.9)$ & $(0.9)$ \\
\hline
\end{tabular}

Color of samples were not degraded during short-term exposure. The highest change for coated wood was found on coating I Alk ( $\Delta b^{*}=-3.5$ units) and uncoated samples $(\Delta b=7.3)$.

Samples coated with either coating I or J were less stable $\left(\Delta E^{*}\right)$. The acrylic waterbased coatings $C$ Alk/Acr and F Acr had better performance at the beginning of the test. 
The overall ranking associated with resistance to color change was: C Alk/Acr $>$ F Acr $>$ A Alk/Acr > I Alk > J Alk > Control.

The color changes after $1800 \mathrm{~h}$ of artificial weathering were statistically different among treatments $(\alpha=0.05)$. Long-term exposure resulted in low resistance to darkening of coated and uncoated samples. The coatings A Alk/Acr, J Alk, and I Alk showed high sensitivity to light degradation $(-12.9,-12.0,11.0$ respectively). This finding corroborates [44], which found effects of aging much earlier in alkyd coatings.

Overall, coatings did not show instability to changes in the $\Delta a^{*}$ spectrum. The highest values were found for coatings A Alk/Acr and C (3.23 and 3.00, respectively). The major change in $\Delta b^{*}$ was measured for coating I Alk ( -12.6 units) followed by coating J Alk and control samples ( -6.7 and 5.5 respectively). The higher color change after $1800 \mathrm{~h}$ of accelerated weathering may be related to the degradation of the protective coatings and the leaching of wood surface components (extractives and lignin). Coating F Acr was the most stable color treatment, which is consistent with the results of other research [44-46] that reported pigmented coatings to be more resistant to photo-degradation than clear coatings.

The gloss of coated and uncoated CLT significantly changed after artificial weathering exposure. Based on the initial surface luster of the samples, the oil-based coatings were affected more after exposure than water-based coatings for either exposure time (Table 5). Oil and alkyd finishes are less permeable and are more likely to decompose as time progresses [45,46]. If the coating is transparent, it is even more susceptible and sensitive to UV-degradation.

Table 5. Gloss change $(\Delta G)$ of coated and uncoated CLT after $360 \mathrm{~h}$ and $1800 \mathrm{~h}$ of artificial weathering (Standard deviation).

\begin{tabular}{ccc}
\hline Treatment & $\Delta G_{360}$ & $\Delta G_{1800}$ \\
\hline \multirow{2}{*}{ A. Alk/Acr } & -0.5 & -0.7 \\
C. Alk/Acr & $(0.4)$ & $(0.1)$ \\
& 0.2 & 4.2 \\
F. Acr & $(0.4)$ & $(0.9)$ \\
& -0.3 & -0.2 \\
I. Alk & $(0.2)$ & $(0.4)$ \\
& -0.9 & -0.9 \\
J. Alk & $(0.7)$ & $(0.8)$ \\
& -0.9 & -1.2 \\
Control & $(0.7)$ & $(0.2)$ \\
& -0.8 & 1.0 \\
\end{tabular}

Similar results were found by [45], who reported gloss degradation on an oil-based coating after three weeks of artificial weathering exposure. The loss of gloss indicates that degradation is occurring due to non-chemical changes (surface wrinkling) or chemical changes located in the topmost portion of the coating [41].

\section{Conclusions}

Visual rankings and degrees of color change reported for samples exposed to outdoor weathering were highly consistent. In both site locations, coatings C Alk/Acr and F Acr were the most resistant. A reason for their superior performance is likely the inclusion of anti-microbial ingredients in their composition. Coatings A Alk/Acr and J Alk failing to protect the CLT surface coincided with increased mold growth, chalking, erosion, and color change over other treated samples. Gloss changed over time, specifically for coatings I Alk and C Alk/Acr, while other variations were not reported due to low values during initial exposure. Water uptake is influenced by substrate variations (defects, type of grain, earlywood/latewood, and end-joint) and climatic conditions. For these reasons, the effect of coatings on moisture content during exposure was not significant. Combinations of water, temperature, and solar radiation impacted coating performance. Even when the 
wood surface is protected, variations in the CLT panels such as end-joint, cracks, and checks can facilitate water uptake that eventually will result in coating failure, delamination, and fungal attack.

Artificial weathering results were similar to the natural weathering. Coatings A Alk/Acr, I Alk, and J Alk had slight to moderate chalking after long-term exposure. These same coatings were the most sensitive to changes in lightness, color, and gloss. Therefore, an artificial weathering test of $1800 \mathrm{~h}$ or greater may screen potential durable coatings for CLT. However, it is important to consider that in artificial weathering, biological agents such as fungi and bacteria are not present. Once biological factors are added, the service life of coatings will be diminished.

Author Contributions: Conceptualization, M.N., K.M.O., and C.E.S.; methodology, C.E.S., G.d.S.B., M.N., and G.K.; formal analysis, G.d.S.B., D.J.V.L., and C.E.S.; investigation, G.d.S.B., C.E.S., G.K., and K.M.O. writing—original draft preparation, G.d.S.B.; writing—review and editing, C.E.S., D.J.V.L., M.N., K.M.O., and G.d.S.B.; supervision G.d.S.B., and C.E.S.; project administration C.E.S.; funding acquisition, M.N. All authors have read and agreed to the published version of the manuscript.

Funding: This research was funded by USDA Forest Service, grant number FPL \#16-JV-11111136-048. This publication is a contribution of the Forest and Wildlife Research Center, Mississippi State University.

Institutional Review Board Statement: Not applicable.

Informed Consent Statement: Not applicable.

Data Availability Statement: The data presented in this study are available on request from the corresponding author. The data are not publicly available due to ethical restrictions.

Acknowledgments: The authors wish to acknowledge the support of U.S. Department of Agriculture (USDA), Forest Service. Any opinions, findings, conclusion, or recommendations expressed in this publication are those of the author(s) and do not necessarily reflect the view of the U.S. Department of Agriculture.

Conflicts of Interest: The authors declare no conflict of interest.

\section{References}

1. Mallo, M.F.L.; Espinoza, O. Outlook for cross-laminated timber in the United States. BioResources 2014, 9, 7427-7443.

2. Zumbrunnen, P.; Fovargue, J. Mid-rise CLT buildings, the UK's experience and potential for Australia and New Zealand. In Proceedings of the 12th World Conference on Timber Engineering, Auckland, New Zealand, 15-19 July 2012; pp. 91-98.

3. Pei, S.; Rammer, D.; Popovski, M.; Williamson, T.; Line, P.; van de Lindt, J.W. An Overview of CLT Research and Implementation in North America. In Proceedings of the 16th World Conference on Timber Engineering (WCTE), Vienna, Austria, 15-22 August 2016.

4. Morris, P. Optimizing the Design of Mass Timber in Exterior Applications. 2015. Available online: www.durable-wood.com (accessed on 12 December 2020).

5. Williams, R.S. Finishing of Wood. In Wood Handbook: Wood as an Engineering Material; Ross, R.J., Ed.; General Technical Report FPL: Madison, WI, USA, 1999; pp. 15-37.

6. Cappellazzi, J.; Konkler, M.J.; Sinha, A.; Morrell, J.J. Potential for decay in mass timber elements: A review of the risks and identifying possible solutions. Wood Mat. Sci. Eng. 2020, 15, 351-360. [CrossRef]

7. Joshi, A.A.; Pagni, P.J. Fire induced thermal fields in window glass. II- Experiments. Fire Saf. J. 1994, 22, 45-65. [CrossRef]

8. Clausen, C.A. Biodeterioration of Wood. In Wood Handbook: Wood as an Engineering Material; Ross, R.J., Ed.; General Technical Report FPL: Madison, WI, USA, 2010; pp. 1-16.

9. Kataoka, Y.; Kiguchi, M.; Williams, R.S.; Evans, P.D. Violet light causes photodegradation of wood beyond the zone affected by ultraviolet region. Holzforschung 2007, 61, 23-27. [CrossRef]

10. Shupe, T.; Lebow, S.; Ring, D. Wood Decay, Degradation \& Stain. In Causes and Control of Wood Decay, Degradation \& Stain; Louisiana Cooperative Extension Service: Baton Rouge, LA, USA; Louisiana State University Agricultural Center: Baton Rouge, LA, USA, 2008; p. 26.

11. Isaksson, T.; Thelandersson, S. Experimental investigation on the effect of detail design on wood moisture content in outdoor above ground applications. Build. Environ. 2013, 59, 239-249. [CrossRef]

12. Koch, P. Finishing. In Utilization of the Southern Pines; U.S. Southern Forest Experiment Station, USDA: Washington, DC, USA, 1972; pp. 1327-1366.

13. Scheffer, T.C. A climate index for estimating potential for decay in wood structures above ground. For. Prod. J. 1971, 21, 25-31. 
14. APA-The Engineered Wood Association. Cross Laminated Timber Standards; American National Standards Institute: Tacoma, WA, USA, 2018.

15. Lepage, R.; Higgins, J.; Finch, G. Moisture uptake test for CLT floor panels in a tall wood building in Vancouver. In Proceedings of the 15th Canadian Conference on Building Science and Technology, British Columbia Building Envelope Council, Vancouver, BC, Canada, 6-8 November 2017; p. 17.

16. Crespell, P.; Gagnon, S. Cross Laminated Timber: A Primer, FPInnovations, Special Publication (52). Vancouver, British Columbia. 2010. Available online: https:/ / fpinnovations.ca/media/factsheets/Documents/cross-laminated-timber-the-boook. pdf (accessed on 25 November 2020).

17. de Meijer, M.; Thurich, K.; Militz, H. Quantitative measurements of capillary coating penetration in relation to wood and coating properties. Holz Roh Werkst 2001, 59, 35-45. [CrossRef]

18. Bonura, T.; Bussjeager, S.; Christensen, L.; Daisey, G.; Daniels, T.; Hirsch, M.; Jourdain, C.J.; Mall, D.D.; Springate, B.; Wagner, L.E.; et al. Finishes checklist: A guide to achieving optimum coating performance on exterior wood surfaces. Coat. Technol. 2004, $1,36-49$.

19. Pánek, M.; Oberhofnerová, E.; Zeidler, A.; Šedivka, P. Efficacy of hydrophobic coatings in protecting oak wood surfaces during accelerated weathering. Coatings 2018, 7, 172. [CrossRef]

20. Bobadilha, G.S.; Stokes, C.E.; Verly Lopes, D.J. Artificial neural networks modelling based on visual analysis of coated cross laminated timber (CLT) to predict color change during outdoor exposure. Holzforschung 2020. published online ahead of print 2020. [CrossRef]

21. Bobadilha, G.S.; Stokes, C.E.; Kirker, G.; Ahmed, S.A.; Ohno, K.M.; Lopes, D.J.V. Effect of exterior wood coatings on the durability of cross-laminated timber against mold and decay fungi. BioRes 2020, 15, 8420-8433.

22. ASTM D1006 / D1006M-13. Standard Practice for Conducting Exterior Exposure Tests of Paints on Wood; American Society for Testing Material: West Conshohoken, PA, USA, 2013.

23. National Oceanic and Atmospheric Administration-NOAA. Global Summary of the Month Station Details. Mississippi State University Station, 2020. Available online: https: / www.ncdc.noaa.gov/cdo-web/datasets/GSOM/stations /GHCND: USC00228374/detail (accessed on 29 September 2020).

24. National Oceanic and Atmospheric Administration-NOAA. Global Summary of the Month Station Details. Madison Dane CO Regional Airport Station, 2020. Available online: https:/ / www.ncdc.noaa.gov/cdo-web/datasets/GSOM/stations /GHCND: USW00014837 / detail (accessed on 29 September 2020).

25. ASTM D772. Standard Test Method for Evaluating Degree Flaking (Scaling) of Exterior Paints; American Society for Testing Material: West Conshohoken, PA, USA, 2018.

26. ASTM D3274-09. Standard Test Method for Evaluating Degree of Surface Disfigurement of Paint Films by Fungal or Algal Growth, or Soil and Dirt Accumulation; American Society for Transforming Material: West Conshohocken, PA, USA, 2017.

27. ASTM D714. Standard Test Method for Evaluating Degree of Blistering of Paints; American Society for Testing Material: West Conshohoken, PA, USA, 2015.

28. ASTM D4214. Standard Test Method for Evaluating Degree of Chalking of Exterior Paint Films; American Society for Testing Material: West Conshohoken, PA, USA, 2015.

29. ASTM D660-93. Standard Test Method for Evaluating Degree of Checking of Exterior Paints; American Society for Testing and Material: West Conshohocken, PA, USA, 2011.

30. ASTM D661-93. Standard Test Method for Evaluating Degree of Cracking of Exterior Paints; American Society for Testing Material: West Conshohocken, PA, USA, 2011.

31. ASTM D662-93. Standard Test Method for Evaluating Degree of Erosion of Exterior Paints; American Society for Testing Material: West Conshohocken, PA, USA, 2011.

32. ISO 11664-4. Colorimetry_Part 4: CIE $1976 L^{*} a^{*} b^{*}$ Colour Space; International Organization for Standardization: Geneva, Switzerland, 2008.

33. ISO 2813. Paints and Varnishes-Determination of Gloss Value at 20 Degrees, 60 Degrees and 85 Degrees; International Organization for Standardization: Geneva, Switzerland, 2014.

34. SAS Institute Inc. SAS/ACCESS®9.4 Interface to ADABAS: Reference; SAS Institute Inc: Cary, NC, USA, 2013.

35. Stirling, R.; Uzunovic, A.; Morris, P.I. Control of black stain fungi with biocides in semitransparent wood coatings. For. Prod. J. 2011, 61, 359-364. [CrossRef]

36. Schultz, T.P.; Militz, H.; Freeman, M.H.; Goodell, B.; Nicholas, D.D. Development of Commercial Wood Preservatives; American Chemical Society Symposium Series 982; Oxford University Press: Washington, DC, USA, 2008; 655p.

37. Roux, M.I.; Wozniak, E.; Miller, E.R.; Boxall, J.; Botcher, P.; Kropf, F.; Sell, J. Natural weathering of various surface coatings on five species at four European sites. Holz Roh Werkst 1988, 46, 165-170. [CrossRef]

38. ANSI/APA-American National Standard. Standard for Performance-Rated Cross-Laminated Timber; Form No. PRG 320-2019; APA: Tacoma, WA, USA, 2020.

39. Han, Y.; Park, Y.; Yang, S.-Y.; Chung, H.; Chang, Y.-S.; Yeo, H. Dimensional changes of cross-laminated specimens produced under different conditions due to humidity variation. BioRes 2019, 14, 4035-4046.

40. Feist, W.C.; Hon, D.N.S. Chemistry of weathering and protection. In The Chemistry of Solid Wood; Rowell, R.M., Ed.; Advances in Chemistry Series 20; American Chemical Society: Washington, DC, USA, 1984; pp. 401-454. 
41. Wood, K.A.; Cypcar, C.; Hedhli, L. Predicting the exterior durability of new fluoropolymer coatings. J. Fluor. Chem. 2000, 104, 63-71. [CrossRef]

42. Wang, J.Y.; Stirling, R.; Morris, P.I.; Taylor, A.; Lloyd, J.; Kirker, G.; Lebow, S.; Mankowski, M.; Barnes, H.M.; Morrel, J.J. Durability of mass timber structures: A review of the biological risks. Wood Fiber. Sci. 2018, 50, 110-127. [CrossRef]

43. Grigsby, W.; Steward, D. Applying the protective role of condensed tannins to acrylic-based surface coatings exposed to accelerated weathering. J. Pol. Environ. 2018, 26, 895-905. [CrossRef]

44. Feist, W.C. Weathering performance of painted wood pretreated with water-repellent preservatives. For. Prod. J. 1990, 40, 21-26.

45. Berdahl, P.; Akbari, H.; Levinson, R.; Miller, W.A. Weathering of roofing materials-an overview. Constr. Build. Mater. 2008, 22, 423-433. [CrossRef]

46. Grüneberger, F.; Künniger, T.; Zimmermann, T.; Arnold, M. Nanofibrillated Cellulose in Wood Coatings: Mechanical Properties of Free Composite Films. J. Mater. Sci. 2014, 49, 6437-6448. [CrossRef] 